\title{
MEMBANGUN KEHIDUPAN DEMOKRASI MELALUI PENDIDIKAN KEWARGANEGARAAN
}

\author{
Soenarjo*
}

\begin{abstract}
Abstrak
Era reformasi dan demokrasi kini tengah melanda kehidupan bermasyarakat, berbangsa dan bernegara, namun belum juga menemukan format pada kedewasaan demokrasi atau masyarakat yang demokratis, bahkan seringkali muncul sikap dan perilaku yang menyimpang dari norma tatanan masyarakat demokratis. Untuk menjadi masyarakat yang demokratis diperlukan berbagai upaya diantaranya melalaui pendidikan kewarganegaraan.

Tujuan pendidikan kewarganegaraan adalah untuk membentuk warga negara yang demokratis, berkeadaban, cerdas, bertanggungjawab bagi kelangsungan hidup bangsa dan negaranya

Keberhasilan demokrasi ditunjukkan oleh sejauh mana demokrasi sebagai prinsip hidup bersama antar warga negara dan antara warga negara dengan negara dijalankan dan disepakati.

Menjadi demokratis diperlukan norma sebagai rujukan tatanan masyarakat yang demokratis. Diantaranya kesadaran akan pluralisme, musyawarah, kebebasan nurani,persamaan hak dan kewajiban, kejujuran dalam pemufakatan
\end{abstract}

Kata Kunci : Pendidikan Kewarganegaraan, Demokrasi

$\overline{\text { *Dosen PPKn IKIP PGRI Madiun }}$ 


\section{A. Pendahuluan}

Bangsa dan negara Indonesia hingga kini tengah memasuki era reformasi dan transisi atau konsolidasi demokrasi dalam upaya membangun kedewasaan demokrasi. Namun dalam perjalanannya dalam mewujudkan kehidupan yang demokratis banyak jalan yang berliku yang ditandai oleh perilaku warga negara yang menyimpang dari norma masyarakat yang demokratis seperti tindakan anarkisme, tidak menghargai kemanusiaan, tawuran antar kelompok suku bangsa, main hakim sendiri, merajalelanya tindak pidana korupsi.

Meskipun banyak rintangan
untuk menjadi masyarakat yang
demokratis, segenap komponen bangsa
ini harus optimis bahwa tatanan
masyarakat yang demokratis dapat
terwujud. Oleh karena itu banyak cara guna membangun kehidupan yang demokratis, diantaranya melalui pendidikan kewarganegaraan.

Jazim Hamidi dan Mustafa Lutffi (2010;128) mengungkapkan pentingnya pendidikan kewarganegaraan dalam membangun demokrasi. Pendidikan kewargaan (civic education) harus mampu menjadikan dirinya sebagai salah satu instrumen pendidikan untuk pemberdayaan bagi masyarakat, terutama bagi peserta didik yang sedang dalam proses pembelajaran pendidikan ini. Selain itu, pendidikan kewargaan harus dapat juga dijadikan wahana dan instrumen untuk melakukan social engineering dalam rangka membangun modal sosial yang efektif bagi tumbuhnya kultur demokrasi dalam kehidupan masyarakat, berbangsa, dan bernegara serta tumbuhnya masyarakat madani.

Untuk menjadi pilar penegakan demokrasi berkeadaban, pendidikan kewargaan harus berani keluar dari sistem pendidikan yang sangat rigid, otoriter, dan doktriner. Sebab, pendidikan gaya tersebut hanya akan melahirkan budaya bisu (silent culture), yang dapat menjadi kendaraan politik, kepentingan suatu rezim, dan memasung kreativitas peserta didik. Pendidikan yang diberikan kepada perserta didik selayaknya menggunakan suatu pendekatan humanistik untuk mengembangkan kemampuan berpikir dan kreativitasnya.

Solusi yang ditawarkan dalam kerangka pendidikan kewargaan yang berkeadaban adalah metode dan proses pendidikan yang tidak saja memberikan pengetahuan, tetapi juga aktivitas untuk membangun kesadaran, kedewasaan, kemandirian, serta pembebasan. Karakter yang disebutkan pada nilainilai terakhir inilah yang merupakan hakikat pendidikan dan demokrasi atau pendidikan kewargaan.

Pendidikan kewargaan merupakan kebutuhan yang mendesak bagi bangsa dalam membangun demokrasi berkeadaban karena beberapa 
alasan: Pertama, meningkatnya gejala dan kecenderungan political literacytidak "melek" politik dan tidak mengetahui cara kerja demokrasi lembaga-lembaganya. Kedua, meningkatnya political apathism yang ditunjukkan dengan sedikitnya keterlibatan warga negara dalam prosesproses politik. Pembentukan warga negara yang cerdas secara intelektual, emosional, sosial, serta spiritual benarbenar merupakan tuntutan dan keniscayaan. Di sinilah pendidikan kewargaan menjadi sarana yang dibutuhkan oleh negara-negara demokrasi baru (seperti Indonesia) untuk melahirkan generasi muda dan masyarakat luas yang mengetahui nilainilai dan keterampilan yang diperlukan dalam mentransformasikan, mengaktualisasikan, dan melestarikan demokrasi.

Setiap negara memerlukan warga negara yang bertanggung jawab. Amerika Serikat sebagai negara penganut paham demokrasi menerapkan civic education di negaranya agar warga negaranya berkarakter "I" $m$ American". Begitu halnya di Indonesia, dengan ditanamkannya pendidikan kewargaan akan menciptakan warga negara yang sadar akan hak dan kewajibannya. Dengan demikian kehidupan bangsa dan negara tersebut akan terjamin.

\section{B. Pengertian Pendidikan \\ Kewarganegaraan (Civic Education)}

Istilah pendidikan kewarganegaraan beragam dan setiap negara memiliki nama tersendiri sesuai dengan konteks dan kebutuhan yang dikembangkan oleh negara masing masing.

Kunawi Basyir dkk (2011:4) memberikan gambaran yang luas mengenai nama pendidikan kewarganegaraan ini. Dalam sejarah pendidikan tinggi pada era Orde Baru terdapat matakuliah kewiraan yang merupakan matakuliah MKDU (Mata Kuliah Dasar Umum) yang wajib diambil oleh mahasiswa. Meskipun memiliki beberapa kesamaan materi dengan Pendidikan Kewarganegaraan tetapi mata kuliah Kewiraan tetap berbeda, karena mata kuliah itu lebih banyak berisi doktrin politik untuk mendukung pandangan rezim yang berkuasa saat itu. Meskipun pada sisi lain ada juga nilai-nilai pembangunan karakter bangsa yang diajarkan pada mata kuliah tersebut. Demikian pula dengan pendidikan kewarganegaraan yang awalnya hadir sebagai respon terhadap berkembangnya paham demokrasi di dunia. Namun seiring dengan perkembangan politik internasional pendidikan ini harus menyesuaikan dengan konteks lokal di masing-masing negara.

Karena itu pula, meskipun dikembangkan di seluruh dunia, mata kuliah ini dikenal dengan berbagai macam istilah atau nama. Mata kuliah tersebut sering disebut sebagai civic education, citizenship education, dan bahkan ada yang menyebut sebagai democracy education. Mata kuliah 
ini memiliki peran yang srategis dalam mempersiapkan warganegara yang memiliki pengetahuan tentang hak dan kewajibanya, serta mengenalkan isu politik yang tidak hanya terkait dengan hukum, ekonomi dan budaya, tetapi juga bagaimana hubungannya dengan agama. Disamping juga mempersiapkan mereka sebagai warganegara yang berkarakter terbuka, menerima perbedaan, mencintai bangsa dan negara, memegang teguh nilai-nilai luhur bangsa, cerdas, bertanggung jawab dan berkeadaban. Dalam bahasa lain mengacu pada rumusan Civic Internasional (1995), disepakati bahwa pendidikan demokrasi penting untuk pertumbuhan civic culture, untuk keberhasilan pengembangan dan pemeliharaan pemerintahan demokrasi.

Berkaitan dengan pengertiannya, Pendidikan Kewarganegaraan (Civic Education) mempunyai banyak pengertian dan istilah. Dalam majalah The Citizen and Civic, pakar Pendidikan Kewargaan, Henry Randal Waite (1986) merumuskan pengertian Civic sebagi the science of citizenship the relation of man, the individual, to man in organized collections, the individual in his relation to the state (ilmu tentang kewarganegaraan yang mengkaji hubungan antar individu dalam suatu kelompok yang terorganisir, serta individu dengan negara). Mengacu pada konsepsi di atas, Numan Sumantri mendefinisikan civic education sebagai ilmu kewarganagaraan yang membicarakan, setidaknya dua hal: (1) hubungan manusia dengan manusia lain dalam organisasi sosial, ekonomi, dan politik; (2) individu dengan negara.

Di Indonesia istilah Civic Education seringkali diterjemahkan dengan Pendidikan Kewarganegaraan atau Pendidikan Kewargaan. Istilah Pendidikan Kewargaan diwakili oleh Azyumardi Azra dan ICCE UIN Jakarta. Sedangkan istilah Pendidikan Kewarganegaraan diwakili oleh Zamroni, Muhammad Numan Somantri dan Udin S. Winataputra. Sebagian ahli menyamakan Civic Education dengan pendidikan demokrasi (Democracy Education) dan Pendidikan HAM.

Berdasarkan Undang-undang Republik Indonesia Nomor 20 Tahun 2003 tentang Sistem Pendidikan Nasional dan surat keputusan Direktur Jendral Pendidikan Tinggi Departemen Pendidikan Nasional Nomor 43/DIKTI/Kep/2006 tentang Ramburambu Pelaksanaan Kelompok, mata kuliah Pengembangan Kepribadian di Perguruan Tinggi terdiri atas mata kuliah Pendidikan Agama, Pendidikan Kewarganegaraan dan Bahasa Indonesia. Berdasarkan ketentuan tersebut, maka kelompok mata kuliah pengembangan kepribadian tersebut wajib diberikan di semua fakultas dan jurusan di seluruh perguruan tinggi di Indonesia.

Dengan adanya penyempurnaan kurikulum mata kuliah pengembangan kepribadian tersebut, pendidikan kewarganegaraan memiliki paradigma baru, yaitu pendidikan kewarganegaraan berbasis Pancasila. Kiranya akan menjadi sangat relevan jika pendidikan kewarganegaraan di perguruan tinggi dewasa ini sebagai sintesis 
antara "civic education", democracy education", serta "citizenship education" yang berlandaskan Filsafat Pancasila, serta mengandung muatan identitas nasional Indonesia dan muatan makna pendidikan bela negara. Hal ini berdasarkan kenyataan di seluruh negara di dunia bahwa kesadaran demokrasi serta implementasinya harus senantiasa dikembangkan dengan basis filsafat bangsa, identitas nasional, kenyataan dan pengalaman sejarah bangsa tersebut, serta dasar-dasar kemanusiaan dan keadaban. Oleh karena itu, dengan pendidikan kewarganegaraan diharapkan intelektual Indonesia memiliki dasar kepribadian sebagai warga negara yang demokratis, religius, berkemanusiaan dan berkeadaban.

Lebih lanjut Kunawi Basyir dkk (2011:9) mengemukakan standar kompetensi yang diharapkan dan tujuan dari pendidikan kewarganegaraan yaitu, menjadi warga negara yang cerdas dan berkeadaban (civic intelegence and civic culture).

Kompetensi dasar atau yang disebut kompetensi minimal yang akan ditransformasikan dan ditransmisikan terdiri dari tiga jenis. Pertama, pengetahuan kewargaan (civic knowledge) yaitu kemampuan dan kecakapan yang terkait dengan materi inti (Civic Education) yaitu demokrasi, hak asasi manusia, dan masyarakat madani. Kedua, kompetensi sikap kewargaan (civic dispositions) yaitu kemampuan dan kecakapan yang terkait dengan kesadaran dan komitmen warga negara antara lain kesetaraan gender, toleransi, kemajemukan dan lain-lain. Ketiga, kompetensi ketrampilan kewargaan (civic skill) yaitu kemampuan dan kecakapan mengartikulasikan ketrampilan kewargaan seperti berpartisipasi dalam proses pembuatan kebijakan publik, melakukan kontrol terhadap penyelenggaraan negara dan pemerintahan.

Pendidikan Kewarganegaraan (Civic Education) bertujuan untuk membangun karakter (character building) bangsa Indonesia, membentuk kecakapan partisipatif warga yang bermutu dan bertanggungjawab dalam kehidupan bangsa Indonesia, membentuk kecakapan partisipatif warga yang bermutu dan bertanggung jawab dalam kehidupan berbangsa dan bernegara, menjadikan warga negara Indonesia yang cerdas, aktif dan kritis dan demokrastis namun tetap memiliki komitmen menjaga persatuan dan integritas bangsa, serta mengembangkan kultur demokrasi yang berkeadaban yaitu kebebasan, persamaan, toleransi dan tanggung jawab.

Tujuan pendidikan kewarganegaraan akan terwujud harus didukung oleh norma atau tatanan hidup demokratis.

\section{Norma tatanan masyarakat demokratis}

Menurut cendekiawan muslim Nurcholish Madjid, dalam Ubaedillah dan Abdul Rozak (2008:41) pandangan hidup demokratis dapat bersandar pada bahanbahan yang telah berkembang, baik secara teoretis maupun pengalaman praktis di negara-negera yang demokrasinya sudah mapan. Setidaknya ada enam (6) norma atau 
unsur pokok yang dibutuhkan oleh tatanan masyarakat yang demokratis. Keenam norma itu adalah:

Pertama, kesadaran akan pluralisme, Kesadaran akan kemajemukan tidak sekadar pengakuan pasif akan kenyataan masyarakat yang majemuk. Kesadaran atas kemajemukan menghendaki tanggapan dan sikap positif terhadap kemajemukan itu sendiri secara aktif. Pengakuan akan kenyataan perbedaan harus diwujudkan dalam sikap dan perilaku menghargai dan mengakomodasi beragam pandangan dan sikap orang dan kelompok lain, sebagai bagian dari kewajiban warga negara dan negara untuk menjaga dan melindungi hak orang lain untuk diakui keberadaannya.

Jika norma ini dijaiankan secara sadar dan konsekuen diharapkan dapat mencegah munculnya sikap dan pandangan hegemoni mayoritas dan tirani minoritas. Daiam konteks Indonesia, kenyataan alamiah kemajemukan Indonesia bisa dijadikan sebagai modal potensial bagi masa depan dernokrasi Indonesia.

Kedua, musyawarah. Makna dan semangat musyawarah ialah mengharus-kan adanya keinsyafan dan kedewasaan warga negara untuk secara tulus menerima kemungkinan untuk melakukan negosiasi dan kompromi-kompromi sosial dan politik secara damai dan bebas dalam sedap keputusan bersaraa. Semangat musyawarah menuntut agar setiap orang menerima kemungkinan terjadinya "partial functioning of ideals", yaitu pandangan dasar bahwa belum tentu, dan tak hams, seluruh keinginan atau pikiran seseorang atau kelompok akan diterima dan dilaksanakan sepenuhnya. Konsekuensi dari prinsip ini adalah kesediaan setiap orang maupun kelompok untuk menerima pandangan yang berbeda dari orang atau kelompok lain dalam bentuk-bentuk kompromi melalui jalan musyawarah yang berjalan secara seimbang dan aman.

Ketiga, cara haruslah sejalan dengan tujuan. Norma ini menekankan bahwa hidup demokratis mewajibkan adanya keyakinan bahwa cara haruslah sejalan dengan tujuan. Dengan ungkapan lain, demokrasi pada hakikatnya tidak hanya sebatas pelaksanaan prosedur-prosedur demokrasi (pemilu, suksesi kepemimpinan, dan aturan mainnya), tetapi harus dilakukan secara santun dan beradab, yakni melalui proses demokrasi yang dilakukan tanpa paksaan, tekanan, dan ancaman dari dan oleh siapa pun, letapi dilakukan secara sukarela, dialogis, dan saling menguntungkan. Unsurunsur inilah yang melahirkan demokrasi yang substansial.

Keempat, norma kejujuran dalam pemufakatan. Suasana masyarakat demokratis dituntut untuk menguasai dan menjalankan seni permusyawaratan yang jujur dan sehat untuk mencapai kesepakatan yang memberi keuntungan semua pihak. Karena itu, faktor ketulusan dalam usaha bersama mewujudkan tatanan sosial yang baik untuk semua warga negara merupakan hal yang sangat penting dalam membanguan tradisi demokrasi. Prinsip ini erat kaitannya dengan paham musyawarah seperti telah 
dikemukakan di atas. Musyawarah yang benar dan baik hanya akan berlangsung jika masing-masing pribadi atau kelompok memiliki pandangan positif terhadap perbedaan pendapat dan orang lain.

$$
\text { Kelima, kebebasan nurani, }
$$
persamaan hak, dan kewajiban. Pengakuan akan kebebasan nurani (freedom of conscience), persamaan hak dan kewajiban bagi semua (egalitarianism) merupakan norma demokrasi yang harus diintegrasikan dengan sikap percaya pada iktikad baik orang dan kelompok lain (trust attitude) Norma ini akan berkembang dengan baik jika ditopang oleh pandangan positif dan optimis terhadap manusia. Sebaliknya, pandangan negatif dan pesimis terhadap manusia dengan mudah akan melahirkan sikap dan perilaku curiga dan tidak percaya kepada orang lain. Sikap dan perilaku ini akan sangat berpotensi melahirkan sikap enggan untuk saling terbuka, saling berbagi untuk kemaslahatan bersama atau untuk melakukan kompromi dengan pihak-pihak yang berbeda.

Keenam, trial and error (percobaan dan salah) dalam berdemokrasi. Demokrasi bukanlah sesuatu yang telah selesai dan siap saji, tetapi ia merupakan sebuah proses tanpa henti. Daiam kerangka ini demokrasi membutuhkan percobaan-percobaan dan kesediaan semua pihak untuk menerima kemungkinan ketidaktepatan atau kesalahan dalam praktik berdemokrasi.

Untuk meminimalkan unsur-unsur negatif demokrasi, partisipasi warga negara mutlak dibutuhkan. Sebagai negara yang masih minim pengalaman berdemokrasinya, Indonesia masih membutuhkan percobaanpercobaan dan "jatuh bangun" dalam berdemokrasi. Kesabaran semua pihak untuk melewati proses-proses demokrasi akan sangat menentukan kematangan demokrasi Indonesia di masa yang akan datang.

Namun demikian, demokrasi juga membutuhkan ketegasan dan dukungan pemerintah sebagai alat negara yang memiliki kewajiban menjaga dan mengembangkan demokrasi. Demi tegaknya prinsip demokrasi, keterlibatan warga negara sangatlah penting untuk mendorong negara bersikap tegas terhadap tindakan kelompokkelompok yang berupaya mencederai prinsip-prinsip demokrasi. Pandangan sektarian dan tindakan memaksakan kehendak kelompok atas kepentingan umum bisa dikategorikan ke dalam hal-hal yang dapat mencederai kemurnian demokrasi. Ketegasan negara Ketegasan negara bisa ditunjukkan dengan menindak tegas, misalnya, sekelompok warga negara yang bertindak anarkis terhadap warga negara yang lain. Dalam negara demokrasi, alat kematangan demokrasi keamanan negara (polisi) adalah satu-satunya aparat hukum yang berwenang atas ketertiban umum. 


\section{Daftar Pustaka}

Jazim Hamidi, Mustafa Lutfi, 2010, Civic

education Antara Realitas Politik dan

Implementasi Hukumnya, Jakarta, Gramedia

Pustaka Utama.

Janedjri M Gaffar, 2012, Demokrasi

Konstitusional Praktek Ketatanegaraan

Indonesia Setelah Perubahan UUD 1945,

Jakarta, Konpress

Kunawi Basyir dkk, 2011, Civic Education,

Surabaya, IAIN Sunan Ampel Press.

Miriam Budiardjo, 2002, Dasar-Dasar Ilmu

Politik, Jakarta, Gramedia Pustaka Utama

Nimatul Huda, 2007, Hukum Tata Negara

Indonesia, Jakarta, Rajagrafindopersada

Ubaedillah dan Abdul Rozak, Pendidikan

Kewargaan, Jakarta, ICCE UIN Syarif

Hidayatullah.

Winarno, 2007, Paradigma Baru

Pendidikan Kewarganegaraan, Jakarta,

Bumi Aksara. 